\title{
Islamic finance for entrepreneurship activities and economic growth: a parametric and non-parametric analysis from Malaysia
}

\author{
Mohammed Ayoub Ledhem \\ Department of Economics, University Centre of Maghnia, \\ Maghnia, Algeria, and \\ Warda Moussaoui \\ Department of Economics, Dr Yahia Fares University of Medea, \\ Medea, Algeria
}

\begin{abstract}
Purpose - The purpose of this paper is to investigate the link between Islamic finance for entrepreneurship activities and economic growth in Malaysia within the model of endogenous growth.

Design/methodology/approach - This study applied a parametric analysis represented by vector autoregression (VAR) Granger causality and a non-parametric analysis represented in the bootstrapped quantile regression to examine the effect of Islamic finance for entrepreneurship activities on economic growth within the model of endogenous growth. This paper used a sample of all Islamic banks working in Malaysia covering a period from 2014 first quarter until 2019 third quarter (2014Q1-2019Q3).

Findings - The findings demonstrated that Islamic finance for entrepreneurship activities are promoting economic growth in Malaysia which indicates that Islamic finance is a vital contributor to economic growth through financing entrepreneurial domains small and medium-sized enterprises.

Practical implications - The analysis in this paper would fill the literature gap by investigating the link between Islamic finance for entrepreneurship activities and economic growth within the model of endogenous growth in Malaysia as this study serves as a guide for the researchers and decision-makers to the necessity of merging Islamic finance as a major player in the economy to finance the entrepreneurial domain which contributes to economic growth.

Originality/value - This study is the first that investigates the relationship between Islamic finance for entrepreneurship activities and economic growth empirically using the causality and quantile regression within a new theoretical approach over the model of endogenous growth to provide a proven valuable experiment from Malaysia concerning Islamic finance for the entrepreneurial domain which promotes economic growth.
\end{abstract}

Keywords Islamic finance, Entrepreneurship activities, Economic growth, Endogenous growth model, VAR Granger causality, Bootstrapped quantile regression

Paper type Research paper

(C) Mohammed Ayoub Ledhem and Warda Moussaoui. Published in PSU Research Review. Published by Emerald Publishing Limited. This article is published under the Creative Commons Attribution (CC BY 4.0) licence. Anyone may reproduce, distribute, translate and create derivative works of this article (for both commercial and non-commercial purposes), subject to full attribution to the original publication and authors. The full terms of this licence maybe seen at http://creativecommons.org/ licences/by/4.0/legalcode

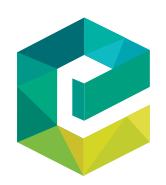

PSU Research Review Emerald Publishing Limited DOI 10.1108/PRR-02-2021-0012 


\section{Introduction}

Lately, the Islamic financial industry in Malaysia is growing quickly amid the mainstream financial sector. The number of Islamic banks grew from just 2 in 2004 to 16 in 2019, with the network of institutions expanding from 136 in 2004 to 2,039 in 2008 (Abd. Majid and H. Kassim, 2015; Islamic Financial Services Board [IFSB], 2020).

The Islamic finance sector provides job incentives for more than 6,700 employees in 2008, relative to about 4,000 in 2004. Under the expansion of the banking system, The Islamic banking sector has also generated durable financial performance, as shown by the fast growth in assets (Abd. Majid and H. Kassim, 2015; Islamic Financial Services Board [IFSB], 2020).

Islamic finance assets increased significantly from US $\$ 2,000 \mathrm{~m}$ in 2004 to US $\$ 689$, US $\$ 720.58 \mathrm{~m}$ in 2018. Islamic finance assets have been gradually growing since the early 2000 s with annual growth of $15 \%-25 \%$. The Islamic finance industry's revenue rose from RM 2.4bn in 2004 to RM 28.9bn in 2018 (Abd. Majid and H. Kassim, 2015; Islamic Financial Services Board [IFSB], 2020).

After more than 40 years, as its establishment, Malaysia's Islamic finance industry has experienced impressive success and accelerated transition. Malaysia has become a model country for others who want to develop the Islamic finance industry and Islamic capital (bonds) markets (DinarStandard, 2020). Nowadays, Malaysia becomes the leading country in issuing Sukuk (Rahman et al., 2020). As well, according to Reuters (2020), Malaysia is the best-performing country in Islamic finance with a global Islamic economy indicator score equals to 111 after an Islamic finance development indicator score equals 132 based on Islamic Finance Development Report 2018 (2019).

Moreover, this vast performance of the Islamic finance industry in Malaysia has synchronized a high level of economic growth because Malaysia's economy stretched 4.9\% year-on-year in the second quarter of 2019, a Successful growth of $4.5 \%$ in the previous threemonth period and thrashing market forecasts of 4.8\% (Trading Economics Database, 2019).

According to Awang et al. (2016), Islamic finance is stimulating entrepreneurship activities. Certainly, both small and medium-sized enterprises (SMEs) in Malaysia are funded lately by Islamic finance as is shown in (Figure 1).

Figure 1.

Islamic finance for the main entrepreneurship activities development in Malaysia (million/ RM)

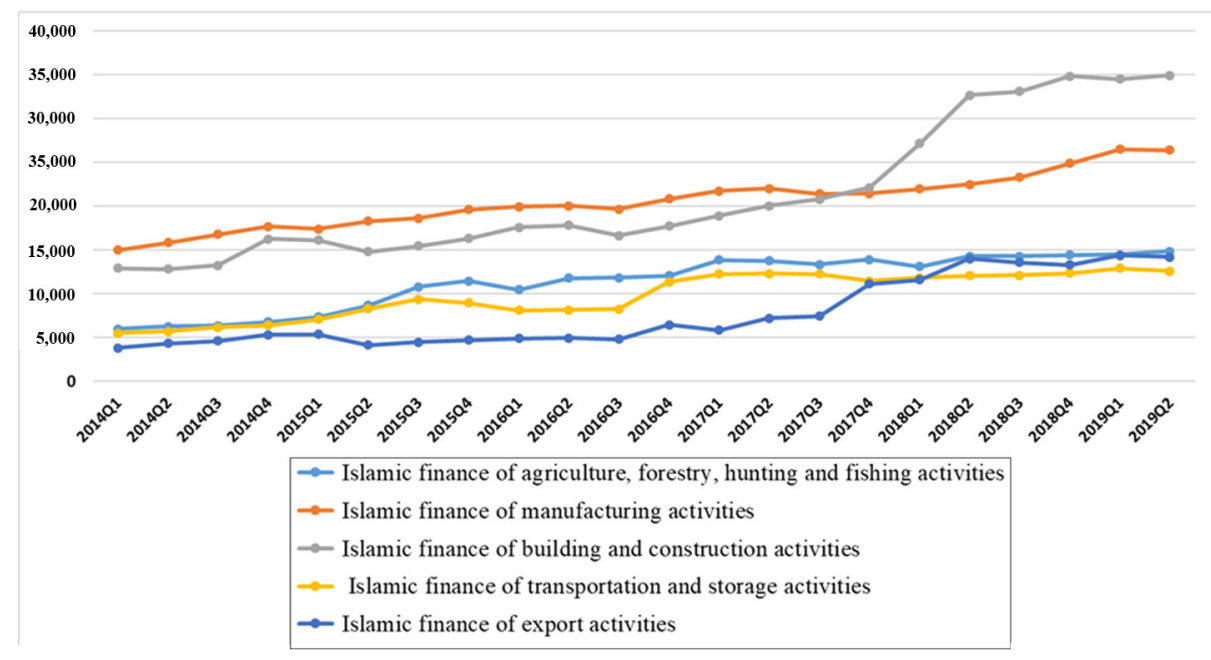

Source: Prepared graph by authors based on Islamic Financial Services Board (IFSB) (2020) 
As small, medium-sized enterprises are anticipated to contribute more than $40 \%$ to the gross domestic product (GDP) of Malaysia by 2020 (Awang et al., 2016), this study investigated whether the Islamic finance for entrepreneurship activities is promoting economic growth based on same growth ratio of the advanced synchronized behavior between Islamic finance for entrepreneurship activities and economic growth as it is shown in (Figure 2). For this reason, this study investigated whether Malaysia is a successful experiment concerning the contribution of Islamic finance for entrepreneurship activities to economic growth.

The contribution of this study is to provide robust empirical evidence, whether IFENT activities are promoting economic growth within the model of endogenous growth. Therefore, this study answers the following question: "Does Islamic finance for entrepreneurship activities promote economic growth in Malaysia?”

\section{Literature review}

\subsection{Islamic finance for entrepreneurship activities and economic growth background within} the model of endogenous growth

The "endogenous growth model" is one in which the long-run growth rate is determined by variables inside the model, not an exogenous proportion of technological progress as in the neoclassical growth concept (Romer, 2011). Jhingan (2011) clarified that the model of endogenous growth underlines practical progress resulting from the rate of investment, the size of the capital stock of human capital. Based on the notable empirical studies of King and Levine (1993a), Levine and Zervos (1998), Rajan and Zingales (1996) and Hassan et al. (2011), banking and finance development contributes to economic growth, which means that finance is an exogenous factor inside the model of endogenous growth.

Kassim (2016) and Tabash and Anagreh (2017) have confirmed that the Islamic finance industry promoting economic growth and investments in the Middle East countries. Thus, according to the model of endogenous growth, when investments increase with the high levels of capital stock because of the banking and financial sector that leads to higher

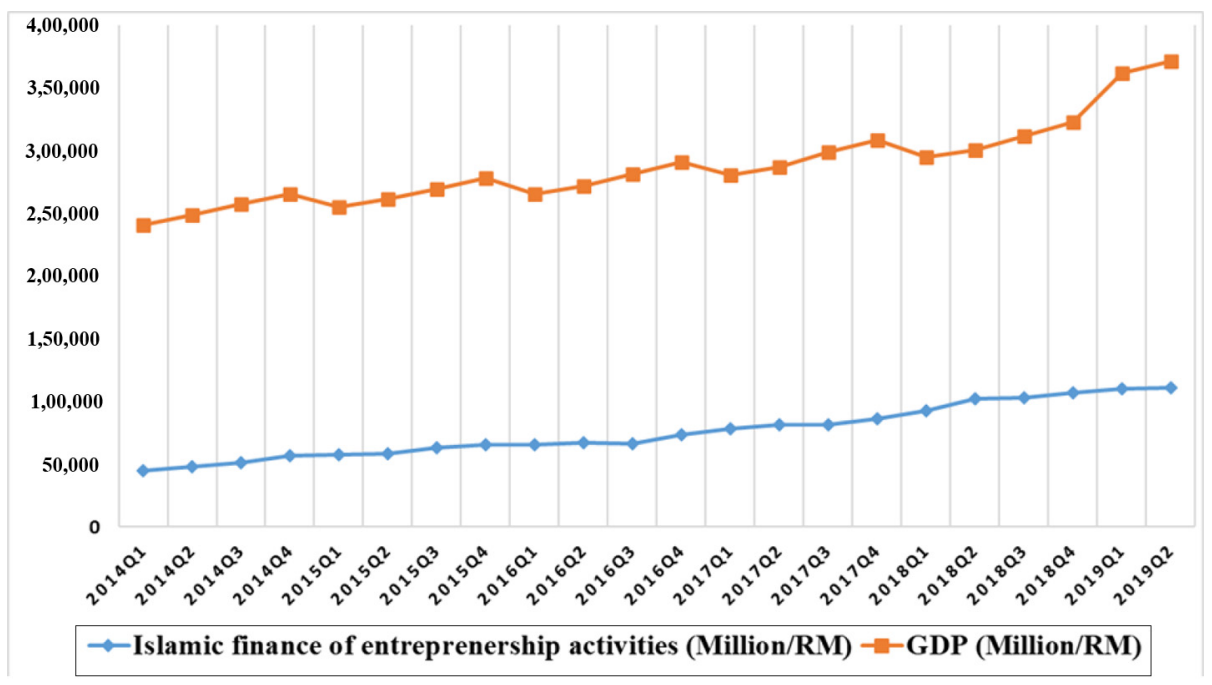

Figure 2. The developed synchronized behavior of both Islamic finance for entrepreneurship activities and economic growth in

Source: Prepared graph by authors based on Islamic Financial Services Board (IFSB) (2020) 
economic growth (Petkovski and Kjosevski, 2014), which means that Islamic finance is an exogenous factor inside the model of endogenous growth.

In conclusion, endogenous economic growth is determined exogenously by Islamic finance due to its significant impact on increasing investments and capital stock. This relationship between Islamic finance and economic growth is an extension of the "supply-leading hypothesis" of Schumpeter identifications (Schumpeter and Redvers, 1934) and compatible with the "financial repression theory" of McKinnon (1973) and Shaw (1973), in which the financial development leads to economic growth. As well, Ledhem (2020) demonstrated that Islamic finance is promoting economic growth through Sukuk (Islamic bonds) markets in Southeast Asia as an exogenous factor within the model of endogenous growth. Besides, based on the study of Ledhem and Mekidiche (2020), Islamic finance is improving economic growth internationally as an exogenous factor in the model of endogenous growth. For this reason, as the Islamic finance for entrepreneurship activities are a part of global Islamic finance that enhances endogenous economic growth, this study examined the impact of Islamic finance for entrepreneurship activities on economic growth in Malaysia within the model of endogenous growth. As well, based on the theoretical analysis of King and Levine (1993b) which construct modelization of endogenous growth from finance and entrepreneurship, the finance mechanism appraises prospective entrepreneurs, organizes savings to finance the most attractive activities to increase productivity that boosts the potential of profitable innovation and thereby increase economic growth, accordingly, financial sector rises the economic growth rate by rising the innovation rate in the entrepreneurial productive sector. Thus, similarly, by projecting this theory of King and Levine (1993b) that is modeled from endogenous growth in this paper, Islamic finance for entrepreneurship activities is an exogenous factor that can improve the economic growth rate by improving the innovation rate in the productive entrepreneurial sector through financing it.

\subsection{Previous empirical studies}

Many studies investigated Islamic finance and economic growth relationship, however, to the best of the authors' knowledge, this is the first study that investigates the relationship between Islamic finance for entrepreneurship activities and economic growth through the endogenous growth perception. Thus, this study is filling a literature gap in which the contribution of this study will support researchers and decision-makers who want to achieve economic growth through new channels in the finance sector.

The main purpose of this study is to focus on the link between Islamic finance for entrepreneurship activities and economic growth; however, pure studies about Islamic finance and entrepreneurship activities through SMEs are limited. To the best of the author's knowledge, only Awang et al. (2016) studied the link between Islamic finance acceptance and the application of Islamic financial planning among SMEs Halal operators in Peninsular Malaysia, their results demonstrated determined that the acceptance of Islamic finance was significantly connected with the application of Islamic financial planning among SMEs Halal operative. Thus, Awang et al. (2016) proved that Islamic finance in Malaysia is playing a major role in financing entrepreneurship activities through SMEs. On the other side, few studies that explored the contribution of financing entrepreneurship activities through the conventional financial system to economic growth, Samila and Sorenson (2011) proved that the rise in venture capital supply affects positively entrepreneurial firms, employment and cumulative revenue which leads to economic growth. Similarly, Stulz (2000) demonstrated that economic growth depends on financial mechanisms that enable financial intermediaries to acquire specialized capital to the entrepreneurship domain. Above and beyond, by focusing only on the contribution of entrepreneurship to economic growth, entrepreneurship proved its key role in enhancing 
economic growth according to Holcombe (1998), Stel et al. (2005), Acs (2006), Galindo and Islamic finance Méndez-Picazo (2013), Adusei (2016) and Ordeñana et al. (2019) when they demonstrated that entrepreneurship is an engine for achieving economic growth.

Besides, as Islamic finance for entrepreneurship activities is a part of total Islamic finance, it is important to indicate the notable studies that investigated the impact of Islamic finance on economic growth, Boukhatem and Moussa (2018) confirmed that the Islamic financial system' development promoted economic growth in the Middle East and North Africa (MENA) region, they used panel cointegration and fully modified ordinary least squares regression on a sample of Islamic banks in the MENA region from 2000 to 2014, they used GDP per capita growth as a dependent variable and total Islamic finance through the loans to the GDP and inflation as independent variables.

In the same vein, Kassim (2016) investigated the impact of Islamic finance on economic growth using a sample of all Islamic banks in Malaysia across a quarterly period from 1998 to 2013 by applying the Autoregressive Distributed Lag (ARDL) method. Kassim (2016) used the industrial production index as a proxy for economic growth which is the dependent variable, total Islamic finance, inflation and gross fixed capital formation (GFCF) as independent variables.

In the same path, Lebdaoui and Wild (2016) examined the connection between economic growth and Islamic finance in Southeast Asia. They applied panel 2SLS and panel ARDL regression across a sample of quarterly data from 2000 to 2012, their study used the ratio of Islamic to conventional financial assets as the independent variable while the GDP per capita as a dependent for economic growth and. Their results demonstrated the presence of a long-run significant impact of Islamic finance on economic growth.

Correspondingly, all those notable studies of Furqani and Mulyany (2009), Abduh and Azmi Omar (2012), Gudarzi Farahani and Dastan (2013), Tabash and Dhankar (2014), Abd. Majid and H. Kassim (2015) and Tabash and Anagreh (2017) have investigated this relationship between Islamic finance and economic growth and settled on a reality that Islamic finance promotes economic growth. Thus, unlike previous studies, this study is enriching the literature by focusing on the link of a part of Islamic finance which is Islamic finance for entrepreneurship activities on economic growth.

Depending on the finding of the previous studies, and based on the perception of the endogenous growth sense which determines that economic growth is driven by Islamic finance, this research frames the hypothesis as the following:

H1. Economic growth is affected positively by Islamic finance for entrepreneurship activities in Malaysia.

\section{Research methodology}

\subsection{Sample and data collection}

This study used data of total Islamic finance for entrepreneurship activities in Malaysia over 16 Islamic banks (Affin Islamic Bank Berhad, Al Rajhi Banking and Investment Corporation (Malaysia) Berhad, Alliance Islamic Bank Berhad, AmBank Islamic Berhad, Bank Islam Malaysia Berhad, Bank Muamalat Malaysia Berhad, CIMB Islamic Bank Berhad, HSBC Amanah Malaysia Berhad, Hong Leong Islamic Bank Berhad, Kuwait Finance House (Malaysia) Berhad, MBSB Bank Berhad, Maybank Islamic Berhad, OCBC AlAmin Bank Berhad, Public Islamic Bank Berhad, RHB Islamic Bank Berhad and Standard Chartered Saadiq Berhad) which were drawn from quarterly data sets of the IFSB database over a period starting from the 2014 first quarter until 2019 third quarter (2014Q1-2019Q3).

Total Islamic finance for entrepreneurship activities is the sum of financing agriculture, forestry, hunting and fishing activities, manufacturing activities, building and construction 
activities, transportation and storage activities, export activities, communication and information activities, arts and entertainment activities, health and social work activities and households as employers.

Other macro data variables like GFCF, trade openness (TRADE) and consumer price index (CPI) were collected from the International Monetary Fund database, Bank Negara Malaysia and Trading economics database (Table 1).

\subsection{Variables}

Following similar studies of Furqani and Mulyany (2009), Abduh and Azmi Omar (2012), Gudarzi Farahani and Dastan, (2013) and Abd. Majid and H. Kassim (2015), in which Islamic finance-economic growth nexus was examined, this research used the GDP as a proxy variable for economic growth.

The exogenous dependent variable is the total Islamic finance for entrepreneurship activities (IFENT) which is a part of the total Islamic financing that has a positive impact on economic growth according to Tabash and Dhankar (2014), Abd. Majid and H. Kassim (2015), Kassim (2016) and Tabash and Anagreh (2017).

To perform the Granger causality test, this study used the GDP and total IFENT activities. Concerning performing the bootstrapped quantile regression, this study used the GDP and total IFENT activities as the main variables. To avoid the problem of biases in the bootstrapped quantile regression model due to omitted variables, other variables were included in the model to control the possible effects of other economic growth determining factors which were adopted based on the previous studies that investigated the link between Islamic finance and economic growth, such as the GFCF as a measured variable of investments (GFCF) (Furqani and Mulyany, 2009; Abduh and Azmi Omar, 2012; Kassim, 2016; Ledhem and Mekidiche, 2020). Trade openness (Furqani and Mulyany, 2009; Gudarzi Farahani and Dastan, 2013; Kassim, 2016; Boukhatem and Moussa, 2018; Ledhem and Mekidiche, 2020) and the CPI as a proxy of inflation (Boukhatem and Moussa, 2018; Kassim, 2016; Ledhem and Mekidiche, 2020) (Table 2).

\subsection{Estimating model}

This research examined the link between Islamic finance for entrepreneurship activities and economic growth within the model of endogenous growth of Romer (2011), to prove empirically that Islamic financing for entrepreneurship activities is within the endogenous economic growth model, Granger vector autoregression (VAR) causality was applied to check if Islamic financing for entrepreneurship activities is causing economic growth in Malaysia.

The estimated model for investigating the relationship between Islamic finance for entrepreneurship activities and economic growth (GDP) is under the following two equations:

$$
\mathrm{GDP}_{\mathrm{it}}=a+\alpha_{1} \mathrm{IFENT}_{\mathrm{it}}+\xi_{\text {it }}
$$

Descriptive statistics summary

\begin{tabular}{lccccc}
\hline Variable & Obs & Mean & Std. dev. & Min & Max \\
\hline GDP (million US\$) & 23 & $80,850.44$ & $7,408.064$ & $65,846.81$ & $9,1123.48$ \\
IFENT (million US\$) & 23 & $19,353.38$ & $4,692.759$ & $13,721.44$ & $2,6981.56$ \\
GFCF (million US\$) & 23 & $20,235.09$ & $1,599.167$ & 16,954 & $2,3611.9$ \\
TRADE & 23 & 1.321643 & 0.0553669 & 1.202234 & 1.423246 \\
CPI & 23 & 116.4531 & 4.268318 & 109.715 & 121.6797
\end{tabular}

Source: Descriptive statistics summary 

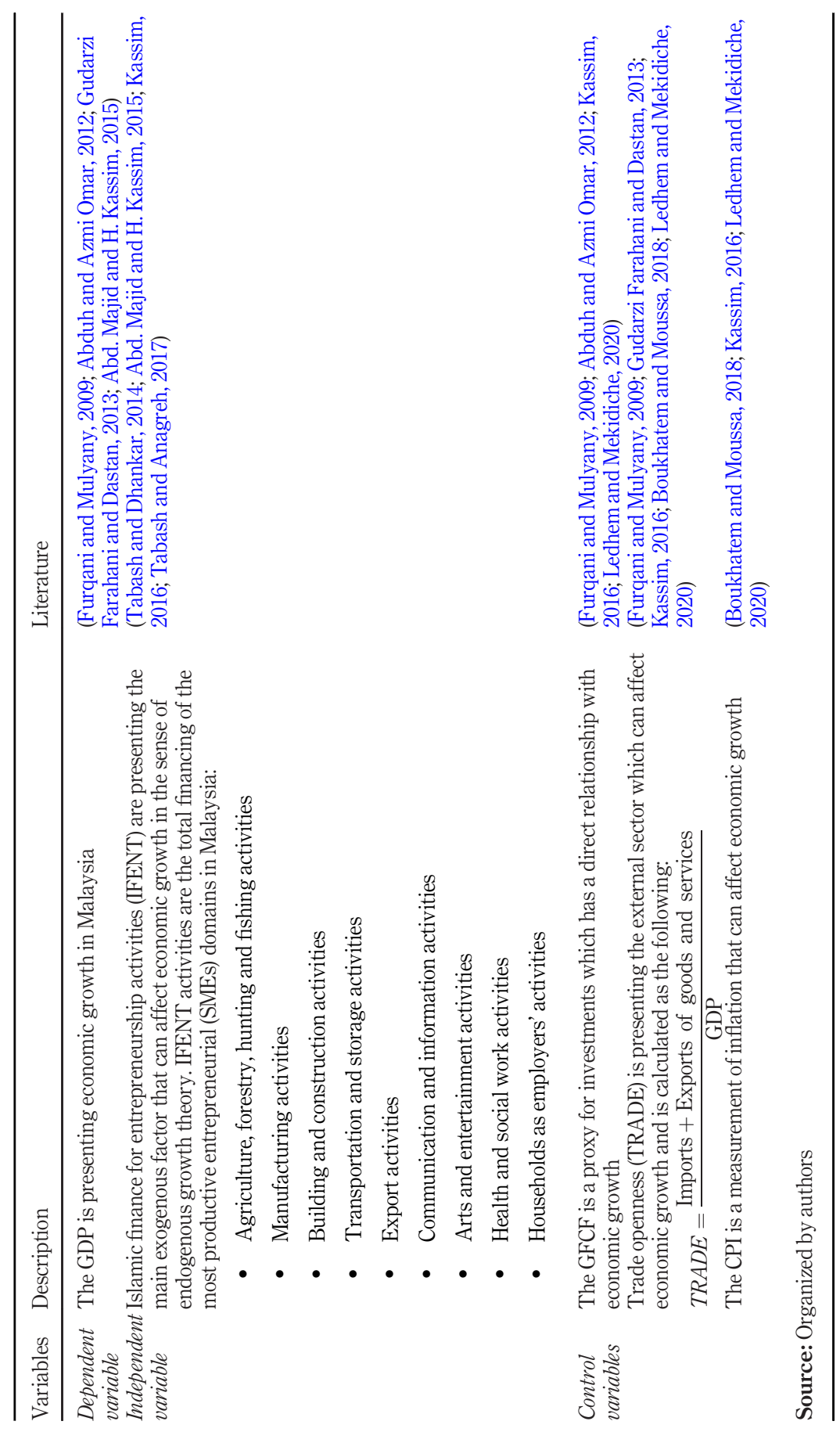

Islamic finance

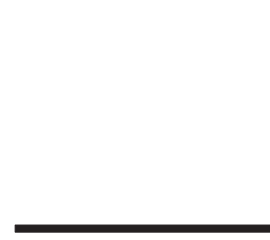

Table 2.

Variable's summary 
Equation (1.1) is for checking the validity that IFENT activities is causing the GDP, where $\alpha_{0}$ is a constant term, $\alpha_{1}$ is a coefficient, $\xi_{\text {it }}$ is an error term, GDP is a dependent variable, IFENT is an independent variable:

$$
\text { IFENT }_{\text {it }}=a s+a \mathrm{GDP}_{\text {it }}+\xi_{\text {it }}
$$

Equation (1.2) demonstrates whether the GDP is causing IFENT activities, where $\alpha_{0}$ is a constant term, $\alpha_{1}$ is a coefficient, $\xi_{\text {it }}$ is an error term, IFENT is a dependent variable, GDP is an independent variable

After checking if Islamic finance for entrepreneurship activities (IFENT) is causing the economic growth (GDP) which is confirming the fact that IFENT activities is an exogenous factor within the model of endogenous growth, this study performed the quantile regression to estimate the impact of Islamic finance for entrepreneurship activities (IFENT) on economic growth (GDP) within the model of endogenous growth with other macroeconomic variables (GFCF, TRADE and CPI) to avoid biases in this estimated model as follows:

$$
\mathrm{GDP}=\mathrm{IFENT}+\mathrm{GFCF}+\mathrm{TRADE}+\mathrm{CPI}
$$

\subsection{Econometric methodology}

3.4.1 Granger causality methodology. The Granger causality is a parametric approach performed in the framework of linear regression models, following Granger (1988), Huynh et al. (2016) and Mills (2019), the Granger causality is performed in a model that involves the $\operatorname{GDP}(y)$ and IFENT activities $(x)$, therefore, the VAR Granger causality can be expressed by:

$$
\begin{aligned}
& y_{t}=\theta_{1}+\sum_{i=1}^{k} \psi_{i} y_{t-i}+\sum_{i=1}^{k} \varphi_{i} x_{t-i}+z_{1 t} \\
& x_{t}=\theta_{2}+\sum_{i=1}^{k} \psi_{2 i} y_{t-i}+\sum_{i=1}^{k} \varphi_{2 i} x_{t-i}+z_{2 t}
\end{aligned}
$$

where:

$\mathrm{K}$ is the optimal lag length, $\theta_{1}, \theta_{2}$ are constant vectors intercept, $z_{t}$ is a random disturbances vector, $\psi$ and $\varphi$ are short-run dynamic coefficients of the model's adjustment long-run equilibrium. $\psi$ and $\varphi$ are sets of regression coefficients matrices, respectively, such that as follows:

$$
\psi_{i}=\left[\begin{array}{ccc}
a_{11, i} & \cdots & a_{1 n, i} \\
\vdots & \ddots & \vdots \\
a_{n 1, i} & \cdots & a_{n n, i}
\end{array}\right] \boldsymbol{\varphi}_{i}=\left[\begin{array}{ccc}
a_{11, i} & \cdots & a_{1 n, i} \\
\vdots & \ddots & \vdots \\
a_{n 1, i} & \cdots & a_{n n, i}
\end{array}\right]
$$

3.4.2 Quantile regression methodology. Following the studies of adopting the non-parametric approach of the quantile regression in the field of banking and economic growth, Mensi et al. (2020) investigated the relationship between Islamic banking development and economic growth with major macroeconomic factors using dynamic panel quantile regression, AbdelRazzaq (2018) studied the determinants of Islamic banking profitability with macroeconomic variables like the GDP using the non-parametric approach of panel quantile regression due to the robustness of estimation in the quantile regression. Also, using the non-parametric approach of the quantile regression in the field of banking, Jiang et al. (2019) used the quantile 
approach to estimate the link between the capital buffer and bank risk-taking. Thus, this study used quantile regression to estimate and investigate whether Islamic banking promotes economic growth. This experimental study applied quantile regression with the bootstrap technique over 1,000 replications for a robust estimation which omits the heteroskedasticity problem in regression (Machado and Silva, 2013; Machado et al., 2019).

The quantile regression methodology is introduced by Koenker and Bassett (1978). It is hired in many practical applications that provide a robust estimation free from the regression heteroskedasticity problem when the interest variables supposedly have diverse effects on the dependent variables conditional distribution (J. A. F. Machado et al., 2019; J. A. Machado and Silva, 2013; Mello and Perrelli, 2003).

Following Koenker and Bassett (1978), the conditional distribution's $\tau$ quantile of $Y_{i}$ given $X_{i}$ is:

$$
Q_{\tau}\left(Y_{i} \mid X_{i}\right)=X_{i}^{\prime} \beta_{\tau}
$$

The constraint vector of the $\tau$ quantile among the conditional distribution is valued by as follows:

$$
\hat{\beta}_{\tau}=\operatorname{argmin} \sum_{i=1}^{N} \rho_{\tau}\left(Y_{i}-X_{i}^{\prime} \beta\right)
$$

where the quantile loss function $\rho_{\tau}($.$) is well-defined as follows:$

$$
\begin{gathered}
\rho_{\tau}(u)=(\tau-1) u \text { for } u<0 \\
\rho_{\tau}(u)=\tau u \text { for } u \geq 0
\end{gathered}
$$

Equation (2.3) displays that the method of quantile regression permits for constraint heterogeneity with diverse values for $\tau$ in the interval $(0,1)$ which are the minimum weighted deviations sum, allowing us to get a whole picture of the bond between an exogenous variable and endogenous variable (Jiang et al., 2019; J. A. F. Machado et al., 2019).

Furthermore, the quantile regression method is robust to outliers and extreme distributions because it can adjust the weight through the loss function. Unlike the OLS regression, the quantile regression does not limit to the standard error term (Jiang et al., 2019; J. A. F. Machado et al., 2019).

Consequently, the estimated model using the quantile regression in this paper is as follows:

$$
\mathrm{GDP}_{\mathrm{t}}=\alpha_{\tau}+\alpha_{\tau 1} \mathrm{IFENT}_{\mathrm{t}}+\alpha_{\tau 2} \mathrm{GFCF}++\alpha_{\tau 3} \mathrm{TRADE}_{\mathrm{t}}+\alpha_{\tau 4} \mathrm{CPI}_{\mathrm{t}}, \quad \tau \in(0,1)
$$

where $\alpha_{\tau}$ is a constant term, $\alpha_{\tau 1}, \alpha_{\tau 2}$ and $\alpha_{\tau 3}$ are coefficients, $t$ is the quarter, GDP is the dependent variable, IFENT is the independent variable. While GFCF, TRADE and CPI are the control variables.

According to Hahn (1995), Feng et al. (2011) and Nikitina et al. (2019), when the sample in modelization is finite and small in the quantile regression, it is recommended to use bootstrapping as an effective technique as a robust resampling technique to get wellestimated results. Thus, as the sample of this study is small with 23 observations, this study applied the quantile regression quantiles with the bootstrap technique over 1,000 replications to understand the total link between Islamic finance for entrepreneurship activities (IFENT) which is the main exogenous variable on economic growth (GDP) which is the endogenous variable. 
3.5.1 VAR Granger causality. To perform the VAR Granger causality correctly based on the paper of Lin (2008), it is important to check that Islamic for entrepreneurship activities (IFENT) and economic growth (GDP) do not contain a unit root in the first difference, after that, it is necessary to determine the optimal lag based on the information criteria to apply the VAR Granger causality.

\section{- Performing unit root tests.}

To check that the GDP and total IFENT activities do not contain a unit root in the first difference, this study performed the Augmented Dickey-Fuller (ADF) unit root test.

Table 3 showed that the autoregressive (1) coefficient of total IFENT activities and GDP series were significantly less than 0.05 based on the ADF test, inferring that the IFENT and GDP do not contain a unit root in the first difference. Concerning the level, both series of IFENT and GDP contains a unit root because of the insignificant $p$-value. Thus, according to Lin (2008), it is suitable to perform the VAR Granger causality on total IFENT activities and GDP, as both of them do not contain a unit root in the first difference.

\section{- Determining optimal lag length for the model.}

According to Table 4, based on Schwarz's Bayesian information criterion (SBIC), the optimal lag length for performing the VAR Granger causality is 1 . However, both the Akaike information criterion (AIC) and Hannan-Quinn information criterion (HQIC) determined that the optimal lag length for performing the VAR Granger test is Lag 3. Thus, this study used Lag 3 as the optimal lag length for the Granger causality test.

Table 3.

Unit root test outputs using the ADF test on total IFENT activities and GDP

\begin{tabular}{|c|c|c|c|c|c|c|}
\hline \multirow[t]{2}{*}{$\begin{array}{l}\text { Variables } \\
\text { Test for unit root }\end{array}$} & \multicolumn{3}{|c|}{$\begin{array}{c}\text { GDP } \\
p \text {-value }\end{array}$} & \multicolumn{3}{|c|}{$\begin{array}{l}\text { IFENT } \\
p \text {-value }\end{array}$} \\
\hline & $\begin{array}{l}\text { No trend, } \\
\text { no } \\
\text { intercept }\end{array}$ & $\begin{array}{l}\text { Including } \\
\text { the drift } \\
\text { term }\end{array}$ & $\begin{array}{l}\text { Including trend } \\
\text { and intercept }\end{array}$ & $\begin{array}{l}\text { No trend, } \\
\text { no } \\
\text { intercept }\end{array}$ & $\begin{array}{l}\text { Including } \\
\text { the drift } \\
\text { term }\end{array}$ & $\begin{array}{l}\text { Including trend } \\
\text { and intercept }\end{array}$ \\
\hline Level & 0.7735 & 0.4836 & $0.0126^{*}$ & 0.9538 & 0.4785 & 0.5614 \\
\hline First difference & $0.0012^{* * *}$ & $0.0003^{* * *}$ & $0.0023^{*}$ & $0.0126 * *$ & $0.0019 * *$ & $0.0244 * *$ \\
\hline
\end{tabular}

Notes: ** Significant at the 0.01 level; * significant at the 0.05 level

Source: ADF test performed by authors

Table 4.
The optimal lag to perform the VAR Granger causality

\begin{tabular}{llll}
\hline Lag & AIC & HQIC & SBIC \\
\hline 0 & 38.2881 & 38.3049 & 38.3875 \\
1 & 35.5148 & 35.5653 & $35.8131^{*}$ \\
2 & 35.7097 & 35.7938 & 36.2068 \\
3 & $35.2414^{*}$ & $35.3592^{*}$ & 35.9373 \\
4 & 35.5981 & 35.7496 & 36.4929
\end{tabular}

Note: *Optimal lag length.

Source: Optimal lag test performed by authors 
According to Table 5, the first null hypothesis is rejected at 0.01 significant level, which means that IFENT activities cause the GDP on a significance level of $1 \%$ ( $p$-value: $0.002<1 \%$ ) while the second null hypothesis is not rejected, which means that the GDP does not cause IFENT activities. Thus, the Granger causality test confirmed that Islamic finance for entrepreneurship activities (IFENT) is affecting economic growth exogenously within the model of endogenous growth. For this reason, this study applied the bootstrapped quantile regression to estimate the impact of IFENT activities on economic growth (GDP).

3.5.2 Quantile regression. To choose the optimal quantiles values for running the regression, this study performed the QRQREG command of Azevedo (2011) to display variation in the coefficient over the conditional quantiles. Thus, Figure 3 provides the graph of

\begin{tabular}{|c|c|c|c|c|c|}
\hline Direction & Excluded & $\chi^{2}$ & $\mathrm{df}$ & Prob $>\chi^{2}$ & \\
\hline \multicolumn{6}{|c|}{$\mathrm{IFENT} \rightarrow \mathrm{GDP}$} \\
\hline GDP & IFENT & 15.075 & 3 & $0.002 * *$ & \\
\hline \multicolumn{5}{|c|}{$\begin{array}{l}\text { GDP } \rightarrow \text { IFENT } \\
\text { Null hypothesis: (GDP) does not Granger cause (IFENT) }\end{array}$} & Table 5. \\
\hline IFENT & GDP & 5.54 & 3 & 0.136 & $\begin{array}{l}\text { Granger causality } \\
\text { test between total }\end{array}$ \\
\hline \multicolumn{5}{|c|}{ Note: **Significant at the 0.01 level } & $\begin{array}{r}\text { IFENT activities and } \\
\text { GDP }\end{array}$ \\
\hline
\end{tabular}
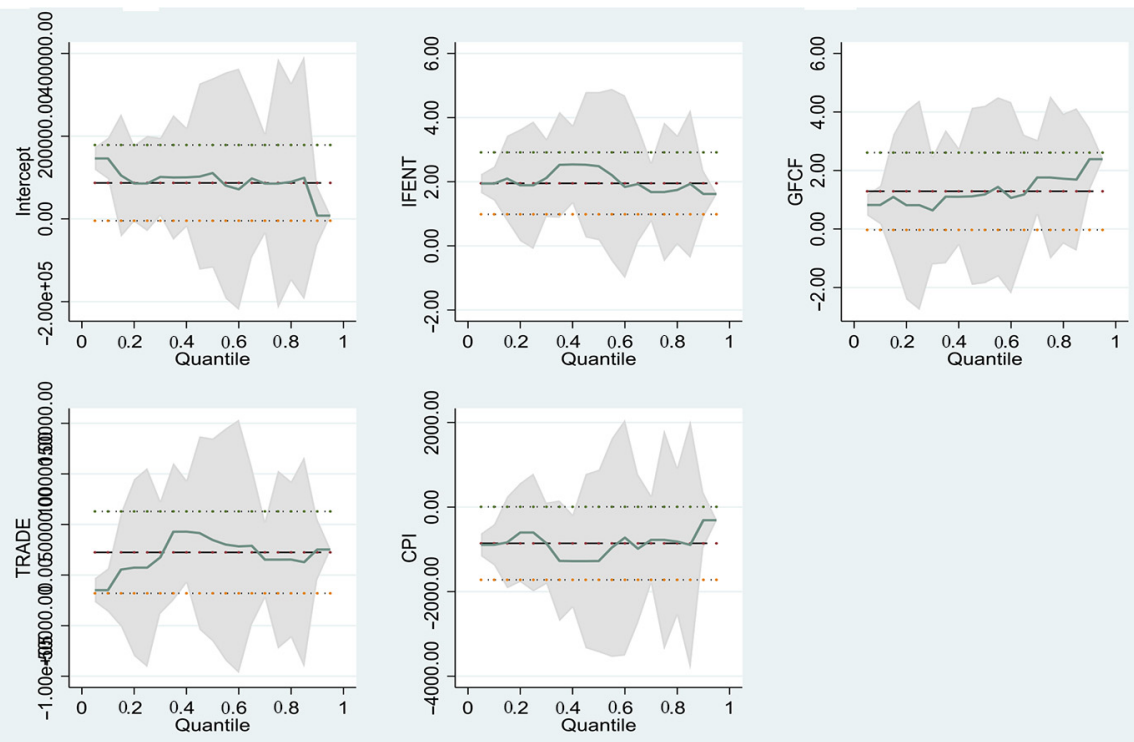

Figure 3.

Graph of the variation in the coefficient over the conditional quantiles

Source: Prepared graph by authors using QRQREG package of Azevedo (2011) 
checking how the Islamic finance for entrepreneurship activities (IFENT) spreads over quantiles $(q)$. The lower quantiles (from $q=0.05$ to $q=0.25$ ) represent low Islamic finance for entrepreneurship activities. Similarly, the intermediate quantiles (from $q=0.25$ to $q=0.50$ ) reflect medium Islamic finance for entrepreneurship activities (IFENT) while the upper quantiles (from $q=0.75$ to $q=0.95$ ) indicate high Islamic finance for entrepreneurship activities (IFENT). Thus, this study performed the quantile regression at $0.25,0.50$ and 0.75 quantiles. Concerning other variables, GFCF, TRADE, CPI and the constant, Figure 3 reported that the quantiles spread over $0.25,0.50$ and 0.75 . As a result, the quantile regression has been performed at a low quantile of 0.25 which reflects that estimating is on a low economic growth of economic recession, intermediate quantile of 0.50 which reflects an intermediate economic growth and at the upper quantile of 0.75 which reflects high economic growth.

Based on Table 6, the highest explanatory power $\left(R^{2}\right)$ is under minimum weighted deviations sum of 0.50 quantiles with $63.77 \%$ that Islamic finance for entrepreneurship activities (IFENT) is explaining strongly the positive effect on economic growth (GDP) with a significance level of $1 \%$ ( $p$-value of IFENT $=0.005<0.01$ ). If there is an increase of $1 \%$ in the Islamic finance for entrepreneurship activities (IFENT) median value then economic growth (GDP) will increase by $2.48 \%$ in the median value.

Whereas the quantile regression on 0.25 quantile shows a significant positive effect of Islamic finance for entrepreneurship activities (FENT) on economic growth (GDP) on a significance level of $5 \%(\phi$-value of IFENT $=0.021<0.05)$ with explanatory power $\left(R^{2}\right)$ of $61.85 \%$. If there is an increase of $1 \%$ in the Islamic finance for entrepreneurship activities (IFENT) median value then economic growth (GDP) will increase by 1.88\% in the median value.

\begin{tabular}{ll}
\hline Simultaneous quantile regression & Number of observations $=23$ \\
\hline Bootstrap replications (1,000) & 0.25 Pseudo $R^{2}=0.6185$ \\
& 0.50 Pseudo $R^{2}=0.6377$ \\
0.75 Pseudo $R^{2}=0.6011$
\end{tabular}

\begin{tabular}{|c|c|c|c|c|c|c|c|}
\hline & GDP & Coef. & $\begin{array}{c}\text { Bootstrap } \\
\text { std. err. }\end{array}$ & $t$ & $p>|t|$ & 95\% Conf. & Interval \\
\hline & IFENT & $\begin{array}{l}0.25 \text { Quantile } \\
1.889639\end{array}$ & 0.7480829 & 2.53 & $0.021 *$ & 0.3179748 & 3.461302 \\
\hline & $\mathrm{GFCF}$ & 0.8128519 & 0.9383592 & 0.87 & 0.398 & -1.158568 & 2.784271 \\
\hline & TRADE & $7,358.07$ & $30,890.59$ & 0.24 & 0.814 & $-57,540.65$ & $72,256.79$ \\
\hline & CPI & -601.2509 & 760.9311 & -0.79 & 0.440 & $-2,199.908$ & 997.406 \\
\hline & Constant & $\begin{array}{l}85,621.73 \\
\text { 0.50 Quantile }\end{array}$ & $71,359.75$ & 1.20 & 0.246 & $-64,299.54$ & 235,543 \\
\hline & IFENT & 2.48463 & 0.769761 & 3.23 & $0.005 * *$ & 0.8674219 & 4.101838 \\
\hline & GFCF & 1.179909 & 0.9713467 & 1.21 & 0.240 & -0.8608146 & 3.220633 \\
\hline & TRADE & $34,680.74$ & $33,248.6$ & 1.04 & 0.311 & $-35,171.97$ & $104,533.5$ \\
\hline & CPI & $-1,274.886$ & 755.218 & -1.69 & 0.109 & $-2,861.54$ & 311.7684 \\
\hline $\begin{array}{l}\text { Table } 6 . \\
\text { Simultaneous }\end{array}$ & Constant & 110,918.6 & $78,182.21$ & 1.42 & 0.173 & $-53,336.09$ & $275,173.4$ \\
\hline quantile regression & IFENT & 1.678615 & 0.7810635 & 2.15 & $0.045^{*}$ & 0.0376615 & 3.319568 \\
\hline with bootstrap & GFCF & 1.759588 & 1.143673 & 1.54 & 0.141 & -0.6431797 & 4.162356 \\
\hline replications on 1.000 & TRADE & $15,218.83$ & $34,126.14$ & 0.45 & 0.661 & $-56,477.54$ & $86,915.19$ \\
\hline at minimum & CPI & -776.1373 & 696.3258 & -1.11 & 0.280 & $-2,239.063$ & 686.7889 \\
\hline $\begin{array}{l}\text { at minimum } \\
\text { weighted deviations }\end{array}$ & Constant & $85,421.26$ & 79,633 & 1.07 & 0.298 & $-81,881.46$ & 252,724 \\
\hline $\begin{array}{l}\text { sum on } 0.25,0.5 \text { and } \\
0.75 \text { quantiles }\end{array}$ & $\begin{array}{l}\text { Note: * } \\
\text { Source }\end{array}$ & $\begin{array}{l}\text { ificant at the } \\
\text { e regression }\end{array}$ & $\begin{array}{l}\text { and } 0.01 \mathrm{le} \\
\text { uts prepar }\end{array}$ & thors & & & \\
\hline
\end{tabular}


Fitting the quantile regression on 0.75 quantile shows an explanatory power of $60.11 \%$ that Islamic finance for entrepreneurship activities (IFENT) is explaining the positive effect on economic growth (GDP) on a significance level of $5 \%$ ( $p$-value of IFENT $=0.045<0.05$ ). If there is an increase of $1 \%$ in the Islamic finance for entrepreneurship activities (IFENT) median value then economic growth (GDP) will increase by $1.67 \%$ in the median value.

As a result, Islamic finance for entrepreneurship activities (IFENT) has a positive effect on economic growth all over $0.25,0.50$ and 0.75 quantiles, which indicates that the increase in Islamic finance for entrepreneurship activities (IFENT) is increasing economic growth in Malaysia. Consequently, this outcome is confirming the validity of the hypothesis that economic growth is affected positively by Islamic finance for entrepreneurship activities (IFENT) in Malaysia. As well, this outcome is consistent with the theoretical analysis of King and Levine (1993b) and Stulz (2000), the empirical analysis of Samila and Sorenson (2011) concerning the significant role of financing entrepreneurship activities to achieve economic growth.

Regarding the control variables, GFCF and trade openness (TRADE) were related positively to economic growth and the CPI was related negatively to economic growth, however, all of these control macro-economic variables and the constants were not significant to economic growth all over quantiles $(0.25,0.50$ and 0.75$)$.

Regarding the estimated model diagnostics based on Koenker and Machado (1999), quantile regression requires to test the slope equality examination of Koenker and Bassett (1982) as a robust procedure for testing heteroskedasticity, symmetric quantile assessment of Newey and Powell (1987) and Ramsey Reset test of stability by Ramsey (1969) (Table 7).

Table 7 reported that the Chi-square $\left(\chi^{2}\right)$ statistic value of the slope equality test is 19.97533 , which is statistically significant $(\phi$-value $=0.0104<0.05)$. So, according to the Wald test, slope equality is rejected at a 5\% significance level, which means that the estimated coefficients are different across quantiles, which leads to conclude that the conditional quantiles are not identical all over $0.25,0.50$ and 0.75 . Besides, Table 7 reported that the $\chi^{2}$-value of the symmetric quantile test is 8.465220 , which is not statistically significant at a $5 \%$ significance level. There is evidence of symmetry ( $p$-value is $0.1324>0.05)$ which leads to conclude that the individual coefficient restriction test value shows no evidence of asymmetry across the quantiles $(0.25,0.50$ and 0.75$)$. As well, concerning the Ramsey reset test, Table 7 reported that the null hypothesis cannot be rejected because of the insignificant $p$-value at the $5 \%$ level ( $p$-value is $0.1047>0.05)$. Thus, there is no misspecification in the model due to omitted variables, as all the coefficients on all

\begin{tabular}{|c|c|c|c|c|}
\hline \multirow[b]{2}{*}{ Test summary } & \multicolumn{2}{|c|}{$\begin{array}{l}\text { Slope equality test } \\
\text { Null hypothesis: slope equality is not different }\end{array}$} & \multirow[b]{2}{*}{ Prob } & \\
\hline & $\chi^{2}$-stat & $\chi^{2} D . F$ & & \\
\hline \multicolumn{5}{|c|}{$\begin{array}{l}\text { Symmetric quantiles test } \\
\text { Null hypothesis: there is no asymmetry in quantiles }\end{array}$} \\
\hline Wald test & 8.465220 & 5 & 0.1324 & \\
\hline $\begin{array}{l}\text { Null hypothesis } \\
\text { QLR L-statistic }\end{array}$ & $\begin{array}{r}\text { in the model } \\
2.633165\end{array}$ & 1 & 0.1047 & $\begin{array}{r}\text { Table } 7 . \\
\text { Bootstrapped }\end{array}$ \\
\hline $\begin{array}{l}\text { Note: } * \text { Signific } \\
\text { Source: Quant }\end{array}$ & s prepared b & & & $\begin{array}{r}\text { quantile regression } \\
\text { diagnostics }\end{array}$ \\
\hline
\end{tabular}


powers are jointly insignificant in the quantile regression, for this reason, the estimated model is stable and accurate against any misspecification of omitted variables, autocorrelation and heteroskedasticity problems.

By performing the diagnostic tests of the slope equality examination of Koenker and Bassett (1982), symmetric quantile assessment of Newey and Powell (1987) and the stability of Ramsey (1969) in the bootstrap quantile regression, this study proved that the estimated results are accurate and robust to answer the research question whether Islamic finance for entrepreneurship activities (IFENT) is enhancing the economic growth in Malaysia.

\section{Conclusion}

This study investigated the relationship between Islamic finance for entrepreneurship activities and economic growth within the model of endogenous growth. The study applied the parametric analysis based on the Granger causality to confirm that Islamic finance for entrepreneurship activities is causing economic growth exogenously inside the model of endogenous growth of Romer (2011), which determines that Islamic finance for entrepreneurship activities is leading to economic growth consistent with the classical theory framework of the "supply-leading hypothesis" of Schumpeter identifications (Schumpeter and Redvers, 1934) and compatible with the financial repression theory of McKinnon (1973) and Shaw (1973). Thus, based on the theoretical analysis of King and Levine (1993b) which construct modelization of endogenous growth from finance and entrepreneurship, the finance mechanism appraises prospective entrepreneurs, organizes savings to finance the most attractive activities to increase productivity that boosts the potential of profitable innovation and thereby increase economic growth, accordingly, financial sector rises the economic growth rate by rising the innovation rate in the entrepreneurial productive sector. Thus, by projecting this theory of King and Levine (1993b) that is modeled from endogenous growth in this paper, Islamic finance for entrepreneurship activities proved its self as an alternate factor of conventional finance which can enhance the economic growth rate by enhancing the innovation rate in the productive entrepreneurial sector through financing it.

To answer the main question of whether Islamic finance for entrepreneurship activities are promoting economic growth in Malaysia, this paper applied the bootstrapped quantile regression as a robust non-parametric method simultaneously over $0.25,0.50$ and 0.75 quantiles. the experimental results showed that the Islamic finance for entrepreneurship activities is positively significant to economic growth all over $0.25,0.50$ and 0.75 quantiles which determines that the increase in Islamic finance for entrepreneurship activities (IFENT) is causing high economic growth in Malaysia. The bootstrap quantile regression confirmed that the best explanatory power is over 0.50 quantiles in which intermediate Islamic finance for entrepreneurship activities explain the positive effect on intermediate economic growth in Malaysia. Thus, as an answer to the main question, Islamic finance for entrepreneurship activities (IFENT) is promoting economic growth in Malaysia.

Consequently, this experimental study has achieved robust evidence that Islamic finance for entrepreneurship activities in Malaysia is a real contribution to economic growth. Additionally, the estimated results confirmed the genuineness validity of the assumption about the positive effect of Islamic finance for entrepreneurship activities on economic growth from the synchronized behavior because of the similar growth ratio between those two factors (Figure 2).

As a result, this study has extracted a real successful experiment from Malaysia concerning the Islamic finance for entrepreneurship activities through SMEs, which can be beneficial for many countries especially those that are still at the beginning of adopting 
Islamic finance as an engine for economic growth through financing the entrepreneurship Islamic finance activities through SMEs.

\subsection{Implications for research and practice}

This study has some implications for research and practice as the following:

- Unlike the existing studies, this study aims to focus on investigating empirically the link between Islamic finance for entrepreneurship activities and economic growth within the model of endogenous growth in Malaysia as a new theoretical framework. Thus, as Islamic finance for entrepreneurship activities is an important part of Islamic finance in Malaysia, the empirical investigation in this paper would fill the literature gap by addressing the slamic finance for entrepreneurship activities' effect on economic growth. Therefore, this study could support researchers and decision-makers who want to achieve economic growth through new financial channels in the banking sector.

- Regarding methodology, this study used two empirical approaches, the first one was by using causality using the Granger var causality to determine that Islamic finance for entrepreneurship activities is causing economic growth as an exogenous factor inside the model of endogenous growth. The second empirical approach was by performing the bootstrapped quantile regression to examine the impact of Islamic finance for entrepreneurship activities on economic growth. Therefore, this study provided a robust answer to conclude that Islamic finance for entrepreneurship activities is promoting economic growth in Malaysia.

- In terms of practical implication, this paper provides important evidence from Malaysia for policymakers, regulators, associated authorities and decision-makers across countries to the necessity of merging Islamic banking and finance as a major player in the financial market and the whole economy to finance the entrepreneurial domain which contributes to economic growth.

\section{References}

Abd. Majid, M.S. and H. Kassim, S. (2015), "Assessing the contribution of Islamic finance to economic growth: empirical evidence from Malaysia", Journal of Islamic Accounting and Business Research, Vol. 6 No. 2, pp. 292-310.

Abdel-Razzaq, A. (2018), "The determinants of islamic banking profitability", Thesis, [Penrith, N.S.W.], Western Sydney University, available at: https://trove.nla.gov.au/version/253787515 (accessed 12 June 2020).

Abduh, M. and Azmi Omar, M. (2012), "Islamic banking and economic growth: the Indonesian experience", International Journal of Islamic and Middle Eastern Finance and Management, Vol. 5 No. 1, pp. 35-47.

Acs, Z. (2006), "How is entrepreneurship good for economic growth?", Innovations: Technology, Governance, Globalization, Vol. 1 No. 1, pp. 97-107.

Adusei, M. (2016), "Does entrepreneurship promote economic growth in Africa?", African Development Review, Vol. 28 No. 2, pp. 201-214.

Awang, M.D., Noor, M.N.A.M., Muhammad, J., Abdullah, A., Rahman, S.A. and Yahya, M.H.D. (2016), "Acceptance and application of Islamic financial planning among small and medium enterprises halal operator in peninsular of Malaysia”, International E-Journal of Advances in Social Sciences, Vol. 2 No. 6, pp. 747-752. 
Azevedo, J.P. (2011), "GRQREG: Stata module to graph the coefficients of a quantile regression, statistical software components", Boston College Department of Economics, available at: https:// ideas.repec.org/c/boc/bocode/s437001.html (accessed 21 September 2020).

Boukhatem, J. and Moussa, F.B. (2018), "The effect of Islamic banks on GDP growth: some evidence from selected MENA countries”, Borsa Istanbul Review, Vol. 18 No. 3, pp. 231-247.

DinarStandard (2020), "State of the global Islamic economy report 2019/20", DinarStandard, available at: www.salaamgateway.com/SGIE19-20 (accessed 3 January 2020).

Feng, X., He, X. and Hu, J. (2011), “Wild bootstrap for quantile regression”, Biometrika, Vol. 98 No. 4, pp. 995-999.

Furqani, H. and Mulyany, R. (2009), "Islamic banking and economic growth: empirical evidence from Malaysia", Journal of Economic Cooperation and Development, Vol. 30 No. 2.

Galindo, M. and Méndez-Picazo, M. (2013), "Innovation, entrepreneurship and economic growth", Management Decision, Vol. 51 No. 3, pp. 501-514.

Granger, C.W.J. (1988), "Causality, cointegration, and control”, Journal of Economic Dynamics and Control, Vol. 12 Nos 2/3, pp. 551-559.

Gudarzi Farahani, Y. and Dastan, M. (2013), “Analysis of Islamic banks' financing and economic growth: a panel cointegration approach", International Journal of Islamic and Middle Eastern Finance and Management, Vol. 6 No. 2, pp. 156-172.

Hahn, J. (1995), "Bootstrapping quantile regression estimators", Econometric Theory, Vol. 11 No. 1, pp. 105-121.

Hassan, M.K., Sanchez, B. and Yu, J.S. (2011), "Financial development and economic growth: new evidence from panel data", The Quarterly Review of Economics and Finance, Vol. 51 No. 1, pp. 88-104.

Holcombe, R.G. (1998), "Entrepreneurship and economic growth”, The Quarterly Journal of Austrian Economics, Vol. 1 No. 2, pp. 45-62.

Huynh, V.N., Kreinovich, V. and Sriboonchitta, S. (2016), Causal Inference in Econometrics, Springer, available at: (accessed 17 June 2020).

Islamic Finance Development Report 2018 (2019), “Thomson Reuters”, available at: www.smefinanceforum. org/post/islamic-finance-development-report-2018 (accessed 11 February 2020).

Islamic Financial Services Board (IFSB) (2020), "Islamic financial services board (IFSB)", available at: www.ifsb.org/psifi_06.php (accessed 11 February 2020).

Jhingan, M.L. (2011), The Economics of Development and Planning, Vrinda Publications, Delhi.

Jiang, H., Zhang, J. and Sun, C. (2019), "How does capital buffer affect bank risk-taking? New evidence from China using quantile regression", China Economic Review, p. 101300.

Kassim, S. (2016), "Islamic finance and economic growth: the Malaysian experience", Global Finance Journal, Vol. 30, pp. 66-76.

King, R.G. and Levine, R. (1993a), "Finance and growth: Schumpeter might be right", The Quarterly Journal of Economics, Vol. 108 No. 3, pp. 717-737.

King, R.G. and Levine, R. (1993b), "Finance, entrepreneurship and growth", Journal of Monetary Economics, Vol. 32 No. 3, pp. 513-542.

Koenker, R. and Bassett, G. (1978), “Regression quantiles”, Econometrica, Vol. 46 No. 1, pp. 33-50.

Koenker, R. and Bassett, G. (1982), "Robust tests for heteroscedasticity based on regression quantiles", Econometrica, Vol. 50 No. 1, pp. 43-61.

Koenker, R. and Machado, J.A.F. (1999), "Goodness of fit and related inference processes for quantile regression", Journal of the American Statistical Association, Vol. 94 No. 448, pp. 1296-1310. 
Lebdaoui, H. and Wild, J. (2016), "Islamic banking presence and economic growth in southeast Asia”, Islamic finance International Journal of Islamic and Middle Eastern Finance and Management, Vol. 9 No. 4, pp. 551-569.

Ledhem, M.A. (2020), "Does Sukuk financing boost economic growth? Empirical evidence from Southeast Asia”, PSU Research Review, available at: https://doi.org/10.1108/PRR-09-2020-0028

Ledhem, M.A. and Mekidiche, M. (2020), "Economic growth and financial performance of Islamic banks: a CAMELS approach", Islamic Economic Studies, Vol. 28 No. 1, pp. 47-62.

Levine, R. and Zervos, S. (1998), "Stock markets, banks, and economic growth", American Economic Review, pp. 537-558.

Lin, J.L. (2008), Notes on Testing Causality, Institute of Economics, Academia Sinica, Department of Economics, National Chengchi University.

McKinnon, R.I. (1973), Money and Capital in Economic Development, Brookings Institution Press.

Machado, J. A F. Parente, P.M.D.C. and Silva, J.M.C.S. (2019), "QREG2: stata module to perform quantile regression with robust and clustered standard errors", Boston College Department of Economics, available at: $\mathrm{https} / / /$ ideas.repec.org/c/boc/bocode/s457369.html (accessed 10 February 2020).

Machado, J.A. and Silva, J. (2013), “Quantile regression and heteroskedasticity”, Accessed, Vol. 5 No. 7 , p. 2015, available at: https://Jmcss.Som.Surrey.Ac.Uk/JM_JSS.Pdf

Mello, M. and Perrelli, R. (2003), “Growth equations: a quantile regression exploration”, The Quarterly Review of Economics and Finance, Vol. 43 No. 4, pp. 643-667.

Mensi, W., Hammoudeh, S., Tiwari, A.K. and Al-Yahyaee, K.H. (2020), "Impact of Islamic banking development and major macroeconomic variables on economic growth for Islamic countries: evidence from panel smooth transition models", Economic Systems, Vol. 44 No. 1, p. 100739.

Mills, T.C. (2019), Applied Time Series Analysis: A Practical Guide to Modeling and Forecasting, Academic Press, available at: (accessed 17 June 2020).

Newey, W.K. and Powell, J.L. (1987), “Asymmetric least squares estimation and testing”, Econometrica, Vol. 55 No. 4, pp. 819-847.

Nikitina, L., Paidi, R. and Furuoka, F. (2019), "Using bootstrapped quantile regression analysis for small sample research in applied linguistics: some methodological considerations", Plos One, Vol. 14 No. 1, p. e0210668.

Ordeñana, X., Vera-Gilces, P., Zambrano-Vera, J. and Amaya, A. (2019), "Does all entrepreneurship matter? The contribution of entrepreneurial activity to economic growth", Academia Revista Latinoamericana de Administración, Vol. 33 No. 1, pp. 25-48.

Petkovski, M. and Kjosevski, J. (2014), "Does banking sector development promote economic growth? An empirical analysis for selected countries in Central and South Eastern Europe", Economic Research-Ekonomska Istraživanja, Vol. 27 No. 1, pp. 55-66.

Rahman, M., Isa, C.R., Tu, T.T., Sarker, M. and Masud, M.A.K. (2020), "A bibliometric analysis of socially responsible investment Sukuk literature", Asian Journal of Sustainability and Social Responsibility, Vol. 5 No. 1, p. 7.

Rajan, R.G. and Zingales, L. (1996), Financial Dependence and Growth, National bureau of economic research.

Ramsey, J.B. (1969), “Tests for specification errors in classical linear least-squares regression analysis”, Journal of the Royal Statistical Society: Series B (Methodological), Vol. 31 No. 2, pp. 350-371.

Reuters, T. (2020), State of the Global Islamic Economy Report 2019/20, Thomson Reuters, DinarStandard, available at: www.salaamgateway.com/SGIE19-20

Romer, D. (2011), "Endogenous growth”, Advanced Macroeconomics, 4th ed., McGraw-Hill, New York, NY, pp. 101-149.

Samila, S. and Sorenson, O. (2011), "Venture capital, entrepreneurship, and economic growth", Review of Economics and Statistics, Vol. 93 No. 1, pp. 338-349. 
Schumpeter, J.A. Redvers, O. (1934), “Theorie der wirtschaftlichen entwicklung. The theory of economic development. An inquiry into profits, capital, credit, interest, and the business cycle... translated. . by Redvers Opie".

Shaw, E.S. (1973), Financial Deepening in Economic Development, Oxford University Press, New York, NY.

Stel, A.V., Carree, M. and Thurik, R. (2005), "The effect of entrepreneurial activity on national economic growth”, Small Business Economics, Vol. 24 No. 3, pp. 311-321.

Stulz, R.M. (2000), "Financial structure, corporate finance and economic growth", International Review of Finance, Vol. 1 No. 1, pp. 11-38.

Tabash, M.I. and Anagreh, S.A. (2017), "Do Islamic banks contribute to growth of the economy? Evidence from United Arab Emirates (UAE)", Banks and Bank Systems, Vol. 12 No. 1, pp. 113-118.

Tabash, M.I. and Dhankar, R.S. (2014), "Islamic financial development and economic growth-empirical evidence from United Arab Emirates", Journal of Emerging Economies and Islamic Research, Vol. 2 No. 3.

Trading Economics Database (2019), "Trading economics report", available at: https:/tradingeconomics. com/malaysia/gdp-growth-annual (accessed 19 January 2020).

\section{Corresponding author}

Mohammed Ayoub Ledhem can be contacted at: ledhem.edu@gmail.com

For instructions on how to order reprints of this article, please visit our website: 